\title{
TANATOLOGIA: ABORDAGEM HISTÓRICO-FILOSÓFICO DA MORTE NO CONTEXTO DA MEDICINA LEGAL E DO DIREITO
}

\section{ARTIGO ORIGINAL}

FIGUEIREDO, Antonio Macena de ${ }^{1}$

FIGUEIREDO, Antonio Macena de. Tanatologia: Abordagem histórico-filosófico da morte no contexto da medicina legal e do direito. Revista Científica Multidisciplinar Núcleo do Conhecimento. Ano 05, Ed. 10, Vol. 09, pp. 26-55. Outubro de 2020.

ISSN:

2448-0959,

Link de acesso: https://www.nucleodoconhecimento.com.br/lei/medicina-legal

\section{RESUMO}

A Tanatologia forense integra um dos ramos da Medicina Legal relacionada aos aspectos científicos com a morte, seus sinais e sua natureza. Não obstante a morte ser fenômeno natural têm implicações na esfera jurídica e social, porém, sempre foi um enigma na cultura ocidental. $O$ objetivo é discutir a temática tanatologia sob três pontos de reflexão: recorte a partir da perspectiva dos filósofos da Antiguidade que mais trabalharam esse tema, a visão da morte no ocidente narrado pelo historiador francês Philippe Ariés e como a Medicina Legal e o Direito tem trabalhado esse tema na prática profissional. Trata-se de estudo de revisão da literatura especializada.

1 Doutor em Ciência da Saúde pela Universidade de Brasília - UNB (area concentração bioética); Mestre em Educação e Ética; Especialista Administração hospitalar e Ética Aplicada e Bioética (FIOCRUZ); Graduado em Direito, Graduado em Enfermagem e Obstetrícia; Advogado; Enfermeiro; Professor Adjunto Aposentado da Universidade Federal Fluminense; Ex-coordenador do Curso de Especialização em Direito Médico da Faculdade de Direito da Universidade do Estado do Rio de Janeiro - UERJ; Ex-presidente da Associação de Direito Médico e Saúde - Adimes; Area de atuação Direito médico e da saúde. Delegado da Comissão de saúde da OAB/RJ/Nit. Pesquisador CNPq. 
Sendo demonstrado como Tanatologia Médico- Legal e do Direito contribuírem para essas reflexões, bem com na definição e conceito de morte, porém, foram os filósofos a partir Platão (428-347 a. C.) e historiadores que esse tema tem sido abordado sob vários aspectos. Conclui-se que a forma de como lidar com esse tema vem se transformando ao longo do tempo. Hoje, o fenômeno morte encontra-se medicalizado, hospitalizado, distanciado da família, da sociedade e até da formação acadêmica. Apesar da Medicina Legal e o Direito serem disciplinas intrinsicamente associadas, o tema ainda está distante tanto do ensino quanto da prática profissional. Evidência que demonstra a necessidade de se rediscutir a temática na formação dos profissionais da medicina e do Direito.

Palavras chaves: Tanatologia, história, Medicina Legal, Direito civil.

\section{INTRODUÇÃO}

"Ninguém acredita na sua própria morte. Ou, dito de outro modo, no seu inconsciente, cada um de nós está convencido da própria imortalidade."

Sigmund Freud.

"Quem morre , não morreu , partiu primeiro A passar este passo estreito, tanto Todos lá havemos de ir por derradeiro."

Luís de Camões.

"Se vale a pena viver; e se a morte faz parte da vida; então morrer também vale a pena."

Kant, E.

A minha morte é possível?

Jacques Derrida, Aporias.

O termo "Tanatologia" vem do grego "Thanatus". Na mitologia grega é o nome dado ao Deus da morte. Já o sufixo "logia", também deriva do grego, significa "estudo". Assim, etimologicamente, a palavra Tanatologia significa o estudo científico da morte; da teoria da morte, de seus sinais e da sua natureza (HOUAISS, 2004). 
Entre os principais temas de estudo destacam-se o luto, a violência, a morte e seus impactos quando veiculadas pela televisão, os cuidados com pacientes graves e em estágio terminal, além de inserir-se na educação das pessoas para lidar com situações de perdas e na formação dos profissionais da Medicina e do Direito (KOVÁCS, 2008).

$\mathrm{Na}$ medicina legal, denominada de Tanatologia médico-legal, cuida das questões relacionadas com a morte. Disciplina que, segundo França (2015) abrange os mais diferentes conceitos de morte, os direitos sobre o cadáver, o destino dos mortos, o diagnóstico de morte, o tempo aproximado da morte, a morte súbita, a morte agônica e a sobrevivência; a necropsia médico-legal, a exumação e o embalsamamento. $E$, entre outros assuntos, ainda analisa a causa jurídica de morte e as lesões in vita e post-mortem.

Nesse aspecto, abrange conhecimentos específicos médicos e do Direito, uma vez que o fenômeno da morte está intimamente ligado à personalidade civil da pessoa e, por isso, tem implicações de extrema relevância na esfera jurídica e social.

Apesar desse tema ser abordado desde as civilizações pré-cristãs, por diferentes culturas e áreas do saber humano, sempre foi um enigma na cultura ocidental. Integra um dos mais vastos e complexos assuntos que envolvem tabu, repulsa, mistérios e sentimentos.

Diferente dos demais animais a única conviç̧ão que o homem tem é a de que um dia morrerá. Para remediar essa certeza cada um se apega a alguma proteção, amparo ou busca refúgio em algo que transcende o próprio mundo físico.

Na história humana, à medida que o homem foi ganhando consciência de si a religião passou a preencher o vazio existencial diante dos mistérios da morte. Tema que sempre constituiu preocupação entre cientistas, moralistas, historiadores e integra o pensamento filosófico de praticamente todos os filósofos desde a Antiguidade.

A presente abordagem discute a temática tanatologia sob três pontos de reflexão: buscou-se fazer um recorte a partir da perspectiva dos filósofos da Antiguidade que mais trabalharam esse tema, a visão da morte no ocidente narrado pelo historiador 
francês Philippe Ariés e como a Medicina Legal e o Direito tem trabalhado esse tema na prática profissional.

\section{PERSPECTIVA DOS FILÓSOFOS DA ANTIGUIDADE}

A morte sempre foi uma sombra que pairou sobre a história da vida humana. Por fazer parte do círculo biológico da vida (nascer, crescer, reproduzir e morrer) contra ela o homem nunca foi capaz de lutar.

Em face das novas possibilidades proporcionadas pelo progresso da ciência pode até retardá-la, porém, jamais conseguirá evitá-la. Por ser um fenômeno natural, à medida que o homem ganhou consciência de si, a religião tem servido como o primeiro ponto de apoio para minimizar o sentimento do luto diante da perda humana.

Percebe-se uma intransponível fronteira entre vivos e mortos que se perpetuam ao longo dos tempos, sendo instrumentalizadas pelos costumes e crenças entre diversos grupos étnicos em diferentes épocas. Talvez seja por isso que constitui um tema onipresente no pensamento filosófico de todo os tempos.

Apesar da Teologia, Antropologia, Sociologia, Psicologia, Tanatologia Médico- Legal e do Direito contribuírem para essas reflexões, foram os filósofos a partir Platão (428347 a. C.), que esse tema tem sido abordado sob vários aspectos.

Em Platão, tem-se a fonte de tudo que foi dito por Sócrates. Em especial, sobre a sua morte em uma de suas obras-primas - o diálogo de Fedão/Fédon, onde narra os fatos que precederam o seu julgamento, sob a acusação de descrença aos Deuses Gregos e corromper a juventude ateniense.

Declarado culpado, assentou-se com indômita fortaleza de ânimo diante do tribunal que o condenou a pena capital. Com 71 anos, foi condenado em 399 A. C. pelo "Tribunal dos Heliastas", compostos por representantes das dez tribos que compunham a democracia ateniense, sendo julgado por 501 membros, com 220 votos a favor de sua absolvição e 281 contra (PLATÃO, 2009). 
O efeito da condenação de seu mestre lhe afetou profundamente e vários de seus diálogos se vinculam a esse evento, bem como serviu de reflexões éticas para os filósofos da época sobre o fenômeno natural da morte. Em um dos diálogos de Fedão/Fédon, por exemplo, pela narrativa de Platão já era possível perceber a visão de Sócrates sobre a morte. Para ele a morte seria a coroação de uma vida virtuosa. A condenação seria um aviso dos Deuses para sair da vida, pois a morte seria o momento em que o espirito se separa do corpo, uma vez que a alma quer libertar-se da imperfeição do corpo: o que denominou de a prisão da alma (SUXO, 2015).

Epicuro (341 a. C. - 270 a. C.), por sua vez, talvez tenha sido o pensador da antiguidade que mais desenvolveu o tema morte. Seu pensamento pode ser resumido na famosa Carta sobre a felicidade (Perì tês eudaimonías), ou Carta a Meneceu, um dos seus mais importantes discípulos.

A sua leitura revela que "não ha nada a temer na morte". Algumas máximas epicuristas preservadas também por Diógenes de Laércio no livro $X$ da obra Vida e Doutrina dos Filósofos ilustres, revelam o esforço de Epicuro em esclarecer que não há sentido em temer a morte (SILVA, 1995).

Inicia a Carta com uma "exortação ao exercício da filosofia", considera desde logo como uma disciplina, cuja meta é justamente tornar feliz o homem que o pratica. No tópico seguinte, trata da morte, sendo apresentada como o mais aterrador dos males. Por isso, salienta: "torna-se absolutamente necessário vencer o medo da morte; ninguém deve temê-la, uma vez que não há nenhuma vantagem em viver eternamente: o que importa não é a duração, mas, a qualidade da vida." (EPICURO, 2002, p. 14/15). Daí Epicuro enfatiza:

Acostuma-te à ideia de que a morte para nós não é nada, visto que todo bem e todo mal residem nas sensações, e a morte é justamente a privação das sensações. A consciência clara de que a morte não significa nada para nós proporciona a fruição da vida efêmera, sem querer acrescentar-Ihe tempo infinito e eliminando o desejo de imortalidade. [...]

O sábio, porém, nem desdenha viver, nem teme deixar de viver; para ele, viver não é fardo e 'não-viver' não é mal (EPICURO, 2002, p. 27/31). 
Para a vida ser boa necessita-se de saúde do corpo e tranquilidade de espírito. A felicidade, por sua vez, é ausência de sofrimentos físicos e de perturbações da alma e o prazer duradouro, está na serenidade do espírito (GOMES, 2003). Uma vez conseguido livrar-se do sofrimento é do medo, acalma-se toda a tempestade da alma, não tendo mais a procurar outra coisa, a não ser o bem da alma e do corpo (PEREIRA, 2019).

Contra a infelicidade, Epicuro ensina a doutrina dos quatros remédios: o Tetrafarmacon (do gr. Łєтрафарнако, termo que significa um medicamento composto de quatro elementos). Assim, por analogia, equipara ao conjunto de quatro máximas fundamentais da ética epicurista: 1a não temer à divindade, que não se preocupa com o homem; $2^{\circ}$ a não temer à morte; $3^{\circ}$ ter em mente a facilidade do prazer; e, $4^{\circ}$ ter em mente a brevidade da dor como suportável (ABBAGNAMO, 2007).

Talvez tenha sido Epicuro o primeiro a formular em proposições, que a morte não deva ser um problema para o homem, enquanto ele vive tem uma clara compreensão do limite desta vida. O motivo de tais reflexões é a de que os homens em geral têm com a morte uma relação de temor; este temor é fonte de tormentos que adoecem a alma e impedem de obter o equilíbrio necessário a uma vida feliz (SILVA, 1995).

$\mathrm{Na}$ Antiga Grécia havia também uma relação muito íntima entre filosofia e a medicina. Tanto para Epicuro, quanto para os seus seguidores, a libertação e a cura se dão pela filosofia. Assim como "o médico se ocupa das doenças e dos sofrimentos do corpo; ao filosofo cabe cuidar das doenças e do sofrimento da alma." (A HISTÓRIA DA FILOSOFIA, 2004, p. 73).

Como Aristóteles (382 a. C. - 322 a. C.), acreditava que o maior objetivo da vida era a felicidade, Epicuro foi além: Achava que a dificuldade em atingir estava no medo que sentimos da morte. Por isso, se propôs a resolver o impasse: se a morte é o fim das sensações, ela não pode ser fisicamente dolorosa, e, se é o fim da consciência, não pode causar dor emocional. Ou seja, não há nada a temer. Superado esse medo, todos podem ser felizes. 
De sorte que, em Epicuro encontra-se uma ética voltada para ensinar a evitar ou a suportar a dor, o medo e o sofrimento, sendo orientado a partir de três temas centrais: a "ataraxia" (termo que designa completa ausência de perturbações ou inquietações da mente), a ausência de medo frente à morte; a caracterização do prazer e a correta compreensão dos desejos, cuja base dessa justificação fundamenta-se por duas razões: o princípio de que toda escolha ou rejeição é o prazer e a dor; por outro lado, o conhecimento do que seja a morte e o vir a ser das coisas, é relativo às experiências acumuladas que permitem generalizar e inferir a verdade única ou múltipla sobre elas (GOMES, 1994).

Assim, o prazer em repouso, como denomina Epicuro, é precisamente a "ataraxia", ou seja, um estado de desejo sempre saciado e que se consegue pelo perfeito equilíbrio entre as partes do organismo (A HISTÓRIA DA FILOSOFIA, 2004). Daí a compreensão de que "o prazer é o início e o fim de uma vida feliz."(EPICURO, 1997, p. 37).

Portanto, se a filosofia tem por finalidade alcançar a "ataraxia", isto e, a imperturbabilidade da alma, e a preocupação com a morte gera perturbação, logo tal preocupação não deve ser objeto da filosofia (SILVA, 1995). Desse modo, o grande mérito de sua ética foi contribuir para a libertação do medo da morte por pretender a ensinar e suportar a dor, o medo e o sofrimento diante de um processo inevitável.

Sêneca (c.55 a. C 39 d. C.) também se interroga como a vida pode ser tão breve a partir de referências dos seus contemporâneos. Aliás, sua vida foi abreviada, pois foi forçado a cometer suicídio, sob a acusação de ter conspiração contra o imperador Nero (SÊNECA, 2008). Dele são duas obras fundamentais, De brevitate vitae e Epistulaes sobre o tema, nas quais aconselha o desprendimento dos prazeres materiais. Ele ensina como eliminar o apego à vida, causa do medo da morte. Afirma que "através do exercício da moderação aplicado aos bens materiais, às situações presentes, e aos projetos futuros, é possível obter melhor aproveitamento do tempo e a supressão do desejo exacerbado das coisas materiais que prendem os indivíduos à vida." (BUCHARD, 2012, p. 124). 
A rigor, não se tem uma vida pela frente, e sim, uma expectativa de vida, que se vive por mais alguns anos, o que não permite deliberar sobre o futuro. Sendo um pensador da escola do estoicismo, aconselha a suportar as adversidades como forma a se preparar para a morte que certamente virá.

A separação da fronteira entre a vida e morte tem sido instrumentalizada pelas religiões e cultos, as quais eram bastante visíveis nas sociedades antigas. De sorte, os comportamentos sobre a morte são concebidos culturalmente e, por isso, variam de uma época para outra por conta das mudanças estruturais sofridas na sociedade ao longo tempo.

Desde a antiguidade esse tema tem sido objeto de reflexões entre os filósofos. Igualmente, as mudanças culturais das sociedades vêm sendo narradas por historiadores. Porquanto, as reflexões sobre a cultura da perda se perpetua até os dias atuais, sendo retomadas em diferentes épocas, seja pela cultura ou valores morais étnicos, seja a partir da filosofia grega ou narrativa de historiadores ou sociólogo.

$\mathrm{Na}$ era medieval (476 a 1453), por exemplo, havia maior preocupação em compreender o papel da humanidade em relação a sua divindade, assim o tema morte era entendido com mais naturalidade e fazia parte do ambiente social. A morte e vida interagiam indiferenciadamente no mundo das aldeias e cidades medievais de acordo com a cultura local.

Em outras épocas, retorna o tema morte a partir do pensamento dos filósofos gregos. Um dos filósofos da modernidade, Michel de Montaigne (1533-1592), na sua filosofia teratológica retoma o diálogo, embora não citam os filósofos estoicos como Sêneca, Cícero, Epicuro e epicurista Lucrécio diretamente, salienta que esses filósofos almejam eliminar sua angústia existencial diante da morte (BUCHARD, 2012).

No ensaio I. 20 - intitulado "que filosofar é aprender a morrer", o qual integra um conjunto de ensaios, Montaigne valendo-se das reflexões morais de autores estoicos e epicuristas, "contrapõe-se àqueles que viram as costas para a morte, tentando a 
todo custo ignorar essa fatalidade inalienável da condição humana: [Isto porque] todos morreremos." (ORIONE, 2012, p. 463-481). Isto porque o próprio apego desenfreado a vida que prejudica nossa existência.

Para Georg Wilhelm Friedrich Hegel (1770 - 1831), na sua obra Fenomenologia do espírito, publicada em 1807, exprime com nitidez o sacrifício de suporta a morte.

Amigo de Friedrich Schelling, foi influenciado pela leitura de Spinoza, Kant e Rousseau, entre outros. No prefácio dessa obra de Hegel deixa claro que a morte e o sacrifício de antemão, tem uma importância fundamental para compreensão da posição natural da vida diante da morte. Ele escreve que:

A morte - se assim quisermos chamar essa inefetividade - é a coisa mais terrível; e suster o que está morto requer a força máxima. A beleza sem força detesta o entendimento porque lhe cobra o que não tem condições de cumprir. Porém não é a vida que se atemoriza ante a morte e se conserva intacta da devastação, mas é a vida que suporta a morte e nela se conserva, que é a vida do espírito (SALVIANO, 2012, p. 196).

Com efeito, como a vida é a posição natural da consciência, a independência sem a absoluta negatividade, sendo assim a morte é a negação natural desta mesma consciência, a negação sem a independência, que assim fica privada da significação pretendida do reconhecimento (SALVIANO, 2012).

Já outro filósofo da contemporaneidade, o alemão Arthur Schopenhauer (1788-1860), também estuda a morte em diversas de suas obras. Apresenta como pedra fundamental de sua filosofia o livro "A metafísica do amor /A metafísica da morte." Para ele, a mesma razão que proporciona a certeza da morte produz também um maravilhoso antídoto contra ela, sendo capaz de anular as vicissitudes da vida. Nesta senda, com a razão apareceu entre os homens, necessariamente, também surge a certeza assustadora da morte. Como assinala Schopenhauer:

Mas, como na natureza, a todo mal sempre é dado um remédio ou, ao menos, uma compensação, então a mesma reflexão, que originou o conhecimento da morte, ajuda também nas concepções metafísicas consoladoras, das quais o animal não necessita, nem é capaz. Sobretudo para esse fim estão orientadas todas as religiões e sistemas 
filosóficos, que são, portanto, antes de tudo, o antídoto da certeza da morte, produzido pela razão reflexionante a partir de meios próprios (SALVIANO, 2012, p. 196).

Novamente, um dos mais notáveis filósofos existencialistas do século XX, Martin Heidegger (1889-1976), retoma o pensamento dos gregos pré-socráticos, mas, é influenciado pelo dinamarquês Sören Kierkegaard e Nietzsche.

Na obra - Ser e o Tempo, publicada em 1927, reeditada várias vezes na língua portuguesa e em outras línguas tratou do tema morte (HEIDEGGER, 2001, 2005, 2007). O que é ser? Essa foi a pergunta inquietante feita Heidegger nessa obra. É dele a ideia também de que apenas diante da morte, o homem adquire um sentido do ser e da liberdade.

Percebe-se que o ponto central de sua teoria é o do sentido de "ser": os modos e as maneiras de enunciação e expressão de ser. Assim, o mais importante está em alcançar o melhor sentido de ser, para enfrentar a morte - o ser-para-a-morte.

Nessa obra também traz o conceito do ser-para-a-morte. O cerne de sua filosofia está na compreensão existencial da morte, ou seja, a morte é uma possibilidade interior do próprio ente. Em outras palavras o ser-no-mundo, é um ser caracterizado pela angústia da morte. Porém, essa disposição deve ter a compreensão de que a morte está presente na sua existência.

O fim da nossa existência quer dizer ser-para-o-fim. Para o ente que existe ser-parao-fim significa ser-para-a-morte. No cotidiano temos a experiência da morte. Seja a morte de alguém que nos é próximo, seja a morte de alguém que nos é distante, a morte de um desconhecido. Ou seja, a morte é sempre a dos outros e nunca a nossa.

A filosofia de Heidegger assume e suporta a morte como uma possibilidade enquanto algo possível a cada instante. Isto é, não uma possibilidade que se pode escolher. Por isso, o suicídio está descartado em sua filosofia, uma vez que suicidar-se é simplesmente fugir da possibilidade natural. 
A sua filosofia rompe também com a tradição acerca da morte à medida que tem como meta possibilitar uma compreensão existencial do ser do "Dasein" (termo que indicava a existência de algo concebido em geral em seu caráter determinado, ou seja, deve ser compreendido como a existência do ser) como ser - ninguém pode morrer no lugar do outro (HEIDEGGER, 2005). Ou seja, a morte é particular de cada um. E cada um deve conhecer o ser, o seu poder-se o seu ser-para-o-fim. "A morte é um modo de ser, que o ser assume, no momento em que é. 'Para morrer basta está vivo'." Frase que ficou consagrada por Heidegger (2001, p. 245).

Epicuro (341 a 270 a. C.) escreveu que enquanto se está vivo a morte não existe e quando ela ocorre não se é mais, logo a morte não existe. Em coerência a esse pensamento, Sigmund Freud (1856-1939), "em vários de seus trabalhos afirmou que não existe a noção de morte no inconsciente." (ZAIDHART, 1990, p. 23).

Em "reflexões para os tempos de guerra e morte" ele retoma as discussões sobre a morte (ZAIDHART, 1990, p. 23). Essas ideias já foram esboçadas em "A interpretação de sonhos", "O tema dos três escrínios" e "Totem e Tabu", "sobre o narcisismo: uma introdução", "luto e melancolia", e em "o Ego e o Id". Segundo Freud ninguém crê em sua própria morte, ou seja, inconscientemente estamos convencidos de nossa imortalidade. "Nosso hábito é dar ênfase à acusação fortuita da morte - acidente, doença, idade avançada; desta forma, traímos um esforço para reduzir a morte de uma necessidade para um fato fortuito." (ZAIDHART, 1990, p. 327/8).

Com esse pensamento o foco passa a ser não a morte em si, mas algum outro evento que a circunda. Desvia-se a atenção para o exterior, para as causas que provocam a morte. Isso é, um mecanismo de defesa do instinto de vida que se sobrepõe ao instinto de morte. Com essa compreensão, pode-se deduzir que o medo da morte não seria dirigido ao próprio corpo, mas sim ao medo da agressão para conseguir a própria auto conservação. Como compreender Freud (1987, p. 75): "o medo da morte aparece como uma reação a um perigo externo e como um processo interno que ocorre entre o Ego e o Superego." 
O homem moderno convive com a ideia de catástrofes a todo o momento. Portanto, diante de tanto descontrole sobre a vida, o homem tenta se defender psiquicamente, de forma cada vez mais intensa contra a morte. "Diminuindo a cada dia sua capacidade de defesa física, atuam de várias maneiras suas defesas psicológicas." (KÜBLER-ROSS, 1998, p. 52/85).

$\mathrm{Na}$ sociedade atual a morte se encontra praticamente eliminada de nosso cotidiano não se morre mais em casa, morre-se isolados nas unidades de terapia intensiva de hospitais, portanto, estrategicamente a morte é ocultada nos hospitais (ARIÉS, 2003), aos olhos frios do sentimento dos profissionais de saúde isolado em leito ou em uma unidade de CTI, sozinho, longe do conforto moral ou espiritual de seus familiares. Antes as pessoas podiam escolher onde iriam morrer, longe ou perto de parentes ou em seu lugar de origem. "já vão longe os dias em que era permitido a um homem morrer em paz e dignamente em seu próprio lar." (KÜBLER-ROSS, 1998, p. 85).

Fazendo um parêntese, o mais desolador, a fragmentação do ensino, produto da especialização crescente do progresso tecnológico da medicina, vem dando a cada dia aos médicos a sensação de poder crescente sobre a doença e a morte. Se de um lado, reflete a tendência, dos futuros profissionais especializar-se na excelência ciência da cura, por outro, quando a doença não cede à terapêutica indicada pelas ditas evidências científicas apontadas pelos estudos nas revistas científicas internacionais, o doente caminha para a morte, sem encontrar nesses profissionais pessoas preparadas psicologicamente para lidar com o sofrimento para o doente e sua família.

Além disso, percebe-se que a medicina paliativa tornou-se área de atuação de múltiplas especialidades que não dialoga entre si. Atualmente, de acordo com a Resolução CFM n, 1.973/2011 existem seis especialidades, as quais na verdade são áreas de atuação, pois a exigência da formação é de apenas de 1 (um) ano em cursos de pós-graduação (geriatria, pediatria, cancerologia, clínica médica, anestesiologia, medicina da família ou Comunidade) e, portanto, cada uma adota seus conceitos, metodologias, protocolos e terapêuticas próprias para uma mesmo seu humano. 
Quiçá, preocupação com o acompanhamento ao luto, já que o cuidado integral campanha o individuo até após a morte.

Por fim, em resumo ao pensamento de Freud, identifica fantasias inconscientes no processo do entendimento individual sobre a morte, que ele considerava como equivalentes ao medo da castração, da perda do amor, da culpa, do luto e da melancolia. A partir de seus estudos surgiram teorias vigorosas que auxiliam os seres humanos a lidarem com a morte, a morte física e as mortes parciais do dia-a-dia (ARAÚJO, 2003).

No entanto, hoje, na visão do homem ocidental, a morte passou a ser sinônimo de fracasso do seu saber, impotência e até vergonha. Tenta-se vencê-la a qualquer custo e, quando tal êxito não é atingido, ela é escondida e negada.

\section{A MORTE NO OCIDENTE NARRADO PELO HISTORIADOR PHILIPPE ARIÈS}

Num esforço de sintetizar o que o sociólogo e historiador Philippe Ariès narrou sobre os ritos e atitudes em torno da morte na sua obra a "História da morte no Ocidente", busca-se destacar alguns pontos para reflexão sobre a morte da Idade Média até o Século XX.

Desde a época medieval conservam-se os sistemas simbólicos envolvendo os ritos fúnebres e o sentimento do luto, uma vez que pouco ou nada mudaram por conta das alterações estruturais ocorridas na sociedade. Entretanto, "a partir do século XVIII o homem das sociedades ocidentais tende a dar à morte um sentido novo." (ARIĖS, 1977, p. 41).

$\mathrm{Na}$ antiguidade havia uma atitude diante da morte sob a ótica da sincronia e da diacronia, conforme expõe Airès (1977). Isto é, enquanto algumas atitudes permanecem praticamente inalteradas, outras surgiram em determinados momentos históricos. Nos tempos antigos a morte era de resignação - a máxima era "morremos todos". Ou seja, a morte era vista com naturalidade. Apesar de sua familiaridade com 
a morte temiam a sua proximidade e procuravam manter a distância. Ou seja, o mundo dos vivos era separado do mundo dos mortos.

Em Roma, por exemplo, "a Lei das Doze Tábuas proibia o enterro in urbe, no interior da cidade." Os cemitérios eram situados fora das cidades, em geral a beira de estradas como Via Appia e os Alyscamps. Apenas uma parte dos cemitérios, ou seja, nas galerias que existiam ao longo do pátio das igrejas ou das catedrais eram cobertas de ossuários, embora estes locais fossem mais reservados para sacerdotes e grandes personalidades da sociedade (ARIÈS, 1977).

O código Teodosiano (compilação de textos jurídicos antigos feitos no período denominado Pós-Clássico a mando de Teodosiano II. Reunia o texto integral de todas as constituições imperiais romanas - publicado em 438) repete a mesma proibição, a fim de que seja preservada a sanctitas das casas dos habitantes. A própria palavra funus significa ao mesmo tempo o corpo morto, os funerais e o assassinato e Funestus a profanação provocada por um cadáver (ARIÈS, 1977).

Para compreender o mistério da morte criaram-se complexos sistemas simbólicos que nada mais são do que os ritos funerários, segundo a cultura dos povos em cada época. Os cerimoniais da partida envolviam diversos passos: A morte é uma cerimônia pública e organizada, era vivenciada pela família e por toda a comunidade e predominava a simplicidade dos ritos da morte sem caráter dramático ou emoção excessiva.

A partir dos séculos XI e XII são introduzidos os aspectos diacrônicos, tendo em vista modificações sutis que, pouco a pouco, deram um sentido dramático e pessoal à familiaridade do homem com a morte, podendo ser traduzida nesta fórmula: "a morte de si mesmo." O homem se sujeita a uma das grandes leis da espécie, porém, não cogita em evitá-la, nem exaltá-la (ARIÈS, 2012, p. 49).

O autor aponta uma série de fenômenos que vão sendo introduzidos no sistema tradicional das representações artísticas: inspirações sobre o Juízo final, o moribundo deitado no seu quarto a espera dos ritos, a tumba como representação do cadáver 
decomposto. Assim, durante a segunda metade da Idade Média, do século XII ao século XV, deu-se uma aproximação entre três categorias de representações mentais:

as da morte, as do reconhecimento por parte de cada indivíduo de sua própria biografia e as do apego apaixonado às coisas e aos seres possuídos durante a vida. A morte tornou-se um lugar em que o homem melhor tomou consciência de si mesmo (ARIĖS, 2003, p. 58).

A partir do século $\mathrm{XVI}$ ao $\mathrm{XVIII}$, o homem das sociedades ocidentais tende a dar à morte um sentido novo - "A morte do outro". A morte agora está sendo representada como uma ruptura. Segundo Ariès (2003) ocorreu duas mudanças no fim do século XVIII: a complacência com a morte do outro e a profunda mudança na relação entre o moribundo e sua família. Diz que desde a alta idade Média até a metade do século XIX, a atitude diante da morte mudou, porém, de forma tão lenta que quase os contemporâneos não se deram conta.

Mas, as mudanças brutais ocorreram no século $X X$; uma delas é a tendência de ocultar o moribundo, a sua real gravidade e o seu estado; enquanto pelos antigos costumes morria-se em casa, o quarto do enfermo foi substituído pelo hospital, à família foi substituída pela equipe de saúde hospitalar e o rito de sepultar o corpo passou para profissionais, sendo cumpridos com extrema brevidade.

Em razão das mudanças dos costumes, do apego à vida e dos avanços da ciência nos últimos sessenta ou setenta anos a doença e a morte passaram para os hospitais e deixou de ocupar o aconchego do lar. O hospital tornou-se o lugar ideal para realizar os cuidados do doente, bem como surgiram profissionais cada vez mais qualificados para prestar assistência direita.

A morte deixa de ser uma condição natural para se transformar em um fenômeno patológico, técnico e transforma-se em evento frio, distante da família, de amigos, de vizinhos e até da sociedade. No hospital o paciente morre cercado de estranhos, de pessoas com as quais não tem afinidade, de profissionais que costumam se aproximar para cumprir uma tarefa ou realizar um procedimento, apenas; de pessoas que utilizando uma língua diferente da usual do seu dia-a-dia e o seu nome passa ser o leito com o número X ou a doença $Z$ (SPLNDOLA, 1994). 
Na primeira obra traduzida para o português em 1977 de Ariès (1977, p. 53/4), já apontava que numerosos sociólogos e psicólogos chocaram-se com os resultados dos estudos sobre a maneira de morrer, com a desumanidade e a crueldade da morte solitária nos hospitais.

A partir do século XVIII, tinha a impressão de que um deslize sentimental fazia passar a iniciativa do moribundo à sua família - uma família na qual tinha toda confiança. Hoje, a iniciativa passou da família, tão alienada quanto o moribundo, ao médico e à equipe hospitalar. São eles os donos da morte, de seu momento e também de suas circunstâncias (ARIÈS, 1977, p. 53/4).

No coetâneo, a morte encontra-se hospitalizada, medicalizada, a anamnese e a conversa com o paciente foram substituídas pela investigação científica, por sofisticados exames, por máquinas que enxergam o paciente por dentro e o organismo passou a ser mantido em funcionamento ao máximo por meio de equipamentos, ou seja, imortaliza-se o mortal e a doença transforma-se em objeto de comércio e de lucro nas instituições privadas ou complementares ao Sistema Único de Saúde.

Os profissionais cada vez mais são treinados para manter o organismo em funcionamento, porém, ao mesmo tempo

sem preparo para assistir às reais necessidades do paciente, em iminência de morte, assim como de sua família. A tecnologia prolonga a vida dos doentes, mas não os ajuda no processo de morrer, sendo o doente terminal marginalizado socialmente porque deixou de ter um papel funcional (MEDEIROS, 2011, p. 206).

O médico tornou-se alvo de todas as expectativas da sociedade, passou e exercer grande influência sobre a doença, sobre o seu tratamento, sobre os anseios dos pacientes e de seus familiares e a sua relação com o paciente vem se fragilizando pelo distanciamento do contato cada vez mais breve com o doente e sua família.

Esse laço tende ainda se afastar em razão do exercício da medicina à distância seja em razão dos sistemas de plantão "stand by" ou do uso dos meios de telecomunicações - telemedicina. Além do que a assistência já é prestada por uma 
equipe, ou seja, cada dia o paciente é assistido por um profissional diferente. Até o enfermeiro tem se afastado do paciente, eis que o passou a ser gerente de Enfermagem, isto é, está deixando de presta os cuidado de enfermagem direto, tarefa reservada agora mais aos setores especializados CTI/UTI.

Neste contexto existem dois paradigmas vinculados à ação de saúde: o curar e o cuidar. No paradigma do curar, o investimento é na vida a qualquer preço, na qual a Medicina de alta tecnologia se torna presente, e as práticas mais humanistas ficam em segundo plano (SPLNDOLA, 1994). Neste sentido a relação com a morte tem se tornado muito impessoal, fria e indireta em função da própria característica da formação acadêmica tecnicista (FIGUEIREDO, 2013). Já no paradigma do cuidar, há uma aceitação da morte como parte da condição humana, não se leva em conta a pessoa doente, e sim somente a doença.

Em função dessa impessoalidade o silêncio sobre a morte chegou ao leito do moribundo, pois a ele é negado até o direito à informação sobre o seu estado de saúde. E, se essa não for uma norma explícita é ao menos uma prática comum, já que se dissimulam ao máximo o que podem para não prestar a devida informação ao moribundo e a seus familiares (GURGEL, 2007).

O exemplo real dessa afirmação encontra-se, hoje, na Resolução do CFM no 1995/2012 (BRASIL, Resolução CFM no 1995 DE 09/08/2012), a qual define as diretivas antecipadas de vontade, ou seja, trata-se do conjunto de desejos, prévios e expressamente manifestados pelo paciente em vida sobre cuidados e tratamentos que quer, ou não, receber no momento em que estiver incapacitado de expressar, livre e autonomamente, sua vontade. Essa norma é extremamente controvérsia no sentido de privilegiar o poder do médico. Ao mesmo tempo em que diz que reconhece a autonomia do paciente, porém, ressalva que desde que se respeite o que está no código de ética médica. Em outras palavras desqualifica e jogo por terra as diretrizes da vontade, eis que a decisão dos seus desejos acaba ficando no poder do médico, ou seja, retorna ao antigo preceito da beneficência hipocrática: médico sujeito e paciente objeto. 
Veja o que diz o art. $2^{\circ}$. "Nas decisões sobre cuidados e tratamentos de pacientes que se encontram incapazes de comunicar-se, ou de expressar de maneira livre e independente suas vontades, o médico levará em consideração suas diretivas antecipadas de vontade." Por outro lado, puxa o tapete: olha o que diz ao contrario o $\S 2^{\circ}$ do sobredito art. "O médico deixará de levar em consideração as diretivas antecipadas de vontade do paciente ou representante que, em sua análise, estiverem em desacordo com os preceitos ditados pelo Código de Ética Médica."

Portanto, justamente diante do grande aumento da expectativa de vida da população mundial, principalmente devido ao desenvolvimento da medicina, retira-se o direito legítimo das pessoas mais vulneráveis falarem antes de morrer, por meio de ato administrativo interno de órgão de classe, pois a decisão ficará sempre na subjetividade da visão paternalista ou da consciência ética e humanística do profissional. Diga-se de passagem, os médicos de defrontam que o seguinte dilema: escuta a foz de sua consciência ou optar por não descumprir a norma, com receio de sofre um processo ético disciplinar.

Por isso, tem-se que se indignar que este tipo de visão sacerdotal, eis que o direito da decisão do cidadão tem que ser garantia em vida, e não deixar ao alvedrio da decisão trivial de órgão disciplinador do exercício profissional. Deve-se lembrar de que o tratamento pelo nosso ordenamento jurídico constitucional não admite discriminação: O objetivo fundamental encontra-se na Constituição da República Federativa do Brasil, no inciso IV do artigo $3^{\circ}$ da Carta Magna, qual seja "promover o bem de todos, sem preconceitos de origem, raça, sexo, cor, idade e quaisquer outras formas de discriminação".

Os termos dessa resolução expõem de modo cruel e acentuado a fragilidade dos idosos, ou seja, justamente aqueles que deveriam receber mais proteção, pois se tornam incapazes de se defender, diante da não garantia de que a sua decisão em vida seja respeito. Norma que vai não contramão das orientações da Declaração Universal de Bioética e Direitos Humanos, construída pelos países-membros das Nações Unidas e aprova na Sessão da Conferência Geral da UNESCO, em Paris, França, realizada em outubro de 2005. 
Mas, conforme já ressaltava Ariès (1989), com a "morte interdita", o novo costume exige que o moribundo morra na plena ignorância da sua morte (ARIÈS, 1977, p. 53/54). Veja, o exemplo do que esta acontecendo com a grave pandemia do covid19 que assolou mundialmente, especialmente, a população mais idosa, pois morreram sem saber as razões da polarização política do uso da hidroxicloroquina e ivermectina e outros medicamentos.

Ver-se, então, que o tema morte constitui-se em um dos maiores enigmas da existência humana; mas, se por um lado, se foi dada a medicina o poder de mudar o curso natural, por outro não se pode esquecer que o seu mais nobre papel é aliviar o sofrimento daqueles que estão prestes a morrer, conforme o postulado de Hipócrates de Cos: primum non nocere - favorecer ou pelo menos, não prejudicar, não atuar quando a doença parecer mortal e atacar a causa do dano (ZAIDHART, 1990).

\section{A MORTE NA PERSPECTIVA DA MEDICINA LEGAL E DO DIREITO}

A Medicina Legal constitui um braço da Medicina. Desde a criação das primeiras Faculdades de Medicina da Bahia e do Rio de Janeiro, em 1832, a Medicina Legal foi introduzida como cadeira na formação profissional. Já no ensino jurídico só veio a integrar a grade curricular das Faculdades de Direito a partir de 1891, por iniciativa de Rui Barbosa (FRANÇA, 2015).

Deste então a Medicina Legal foi definida como uma especialidade médica de forma isolada. Só depois de mais de 2 (dois) séculos, passou a integrar uma especialidade em conjunto com a perícia médica, conforme a Resolução do CFM № 2005/2012 Medicina Legal e perícia médica.

Para Freire, citando Gandolfi a Medicina Legal

é a ciência que tem por objeto a aplicação dos princípios médicos ao Ministério da Justiça Civil, Criminal, Canônica e a análise filosófica de alguns elementos físicos, morais e sociais do homem, que servem de base e ordenamento às instituições e reforma de algumas leis (FREIRE, 2010, p. 30). 
Peixoto, segundo Freire "diz que a Medicina legal é uma aplicação de conhecimentos científicos aos misteres da justiça. Não é uma ciência autônoma, no sentido exato da expressão, mas um conjunto de aquisições de várias origens para um fim determinado." (FREIRE, 2010, p. 36).

França (2015, p.1) na introdução da décima edição de sua obra "Medicina Legal", conceitua como "uma ciência de largas proporções e de extraordinária importância no conjunto dos interesses da coletividade, porque ela existe e se exercita cada vez mais em razão das necessidades da ordem pública e do equilíbrio social."

A "Medicina Legal é a contribuição médica, técnica e biológica às questões complementares dos institutos jurídicos e às questões e ordem pública ou privada quando dos interesses da administração judiciária." Trata-se de uma disciplina jurídica que abrange conhecimentos específicos Médicos e do Direito uma vez que o fenômeno da morte está intimamente ligado à personalidade civil do indivíduo e, por conseguinte, tem implicações de extrema relevância na esfera jurídica e social. Com explica o professor França (2015, p.8) é uma "disciplina jurídica porque foi criada e subsiste em face da existência e das necessidades do Direito."

A Tanatologia, por sua vez, estuda o processo de morte isoladamente ou associada a outras áreas acadêmicas. A Tanatologia Médico-legal é a parte da Medicina Legal que estuda a morte e o morto e suas repercussões jurídico-sociais (FRANÇA, 2011). No âmbito do Direito a Tanatologia é chamada de Tanatologia Forense, pois a morte também tem implicações jurídicas. Se de um lado existe um conceito de morte biológica, do outro, há um conceito jurídico.

Esse ramo da Médico-legal, portanto, ocupa-se da análise dos mais diferentes conceitos de morte, "cuida da morte e do morto, os direitos sobre o cadáver, o destino dos mortos, o diagnóstico de morte, o tempo aproximado da morte, a morte súbita, agônica e a sobrevivência; a necropsia médico-legal, a exumação e o embalsamento." (FRANÇA, 2015, p.8). 
Desde a descoberta da anatomia o cadáver passou a fazer parte, "sem contestação religiosa ou moral, do campo médico." (FOUCAULT, 2013, p. 138). A partir daqui surge à necessidade de se detectar no cadáver os produtos da morte e da doença. Uma vez dessacralizado o corpo pelos anatomistas, o cadáver tornou-se objeto da ciência, passando considerar apenas a sua natureza física e biológica. Se, milenarmente a vida trazia em si a ameaça de doença, e esta, a ameaça de morte, no século XIX, essa relação passa a ser pensada cientificamente, como afirma Foucault:

se até o século XVIII, o médico tinha o olhar dirigido para a vida e a cura de doenças, sendo a morte uma ameaça sombria a seu desempenho, no século XIX, o olhar médico passa a se apoiar na morte como instrumento que lhe possibilita apreender a verdade da vida e a natureza de seu mal (FOUCAULT, 2013, p. 138).

A morte deixa de ser sinal de fracasso para Medicina, uma vez que agora se torna possível identificar as suas causas. De tal modo, o grande corte na história da medicina ocidental data precisamente do momento em que a experiência clínica tornou-se o olhar antomoclínico (FOUCAULT, 2013).

Ainda de acordo com Foucault, é sob a luz da morte que se pode adentrar na obscuridade da vida. Citando Bichat, diz que o lema deste século é formulado da seguinte forma: "Abram alguns cadáveres: logo verão desaparecer a obscuridade que apenas a observação não pudera dissipar." (ZAIDHART, 1990, p. 97).

Assim, a morte passou a integrar um conjunto de conhecimentos científicos e técnicos, seguido de orientações éticas e regras de direitos, eis que as sociedades são regidas por estatutos normativos.

Cabe por fim, questionar como a Medicina Legal e o Direito definem o fenômeno morte e a distinção entre a morte natural, violenta, suas causa suspeita e conclui-se expondo as razões das dificuldades do tema morte ser trabalhado na prática profissional. 


\subsection{CONCEITOS DE MORTE NA ÁREA MÉDICA}

A Tanatognose é a parte da Tanatologia que estuda o diagnostico da realidade da morte. O objetivo primordial é estabelecer a causa jurídica na busca de determinar as hipóteses de homicídio, suicídio ou acidental. Caso em que devem deter-se não penas ao exame do corpo, mais também ao resultado da inspeção do local de morte, o qual é realizado pela perícia criminal (FRANÇA, 2011).

Já o diagnóstico da morte natural é feitos através de inúmeros sinais, denominados de sinais de morte. Porém, concretamente, na prática costuma-se adotar o critério de cessação dos fenômenos respiratório e circulatório (GOMES, 1994), embora prevaleça o conceito de morte encefálica.

O critério de morte encefálica é baseado na cessação total das atividades cerebrais, para fins de retirada de tecido pós mortem, conforme determina 0 art. $3^{\circ}$ da Lei $\mathrm{N}^{\circ}$ 9.434, de 4 de Fevereiro de 1997, que dispõe sobre a remoção de órgãos, tecidos e partes do corpo humano para fins de transplante e tratamento e dá outras providências. In verbis:

Art. $3^{\circ} \mathrm{A}$ retirada post mortem de tecidos, órgãos ou partes do corpo humano destinados a transplante ou tratamento deverá ser precedida de diagnóstico de morte encefálica, constatada e registrada por dois médicos não participantes das equipes de remoção e transplante, mediante a utilização de critérios clínicos e tecnológicos definidos por resolução do Conselho Federal de Medicina (BRASIL, Lei № 9.434, de 04.02.1997).

A morte encefálica ocorre quando existe lesão irreversível de todo encéfalo, sendo constatada por dois médicos não pertencente à equipe de transplante, como previsto no referido dispositivo legal e conforme os critérios éticos definidos pela Resolução CFM no. 1.480/1997, atualizada pela Resolução no 2.173/17, do Conselho Federal de Medicina (BRASIL, Resolução $n^{\circ}$ 2.173/2017).

Um aspecto que é importante enfatizar refere-se ao fato de que o diagnóstico de morte encefálica estabelece-se na presença de coma aperceptivo, irreversível, de causa 
conhecida, ausência de atividade motora supraespinal e apneia, precedida de dois exames clínicos, como prever os artigos $1^{\circ}, 3^{\circ}$ e $4^{\circ}$ da sobredita resolução.

Em resumo, a morte pode ser entendida simplesmente como a perda total e irreversível das funções vitais, porém, é aceita dois distintos conceitos sobre as funções vitais: a morte encefálica e a circulatória.

\subsection{A MORTE NO ÂMBITO LEGAL}

No âmbito legal a morte é vista como o cessar da personalidade civil do de cujus, personalidade esta que começa com o nascimento da pessoa com vida, embora não exista na lei a definição do que seria a morte propriamente dita.

Pode-se a firmar que é o Direito quem demarca o início e o fim da personalidade civil, ou seja, o início da vida e quando ela deixa de existir para o mundo jurídico. Assim, dispõem, respectivamente, os artigos $2^{\circ}$ e $6^{\circ}$, a personalidade civil da pessoa começa do nascimento com vida e termina com a morte:

Art. $2^{\circ}$. A personalidade civil da pessoa começa do nascimento com vida; mas a lei põe a salvo, desde a concepção, os direitos do nascituro.

Art. 6ㅇ A existência da pessoa natural termina com a morte; presume-se esta, quanto aos ausentes, nos casos em que a lei autoriza a abertura de sucessão definitiva. (BRASIL, Código Civil e normas correlatas, 2020, p. 47).

Vê-se que a Medicina Legal, a Tanatologia e o Direito intercruzam-se entre os fenômenos de vida e morte e relaciona-se com diversos ramos do Direito, como Civil, Penal, Constitucional, Trabalhista e outros.

A definição do momento da morte do nascituro, por exemplo, tem consequências jurídicas distintas no Direito Civil: se a morte ocorreu dentro do ventre materno, se nasceu com vida e logo a seguir veio a óbito por causas naturais ou não, são decisivas para a transmissão de bens por doação. 
Vimos na primeira parte do art. $2^{\circ}$ do $C C$ que diz que a personalidade civil começa com o seu nascimento como vida, porém, na segunda parte, ressalta que "a lei põe a salvo, desde a concepção, os direito do nascituro."

Logo é possível o nascituro receber bens em doação por ser sujeito de direito. Se alguém fizer uma doação por livre deliberação, por exemplo, para a criança que estar para nascer, na forma dos arts. 538/542 do CC, para a concretização da transmissão desse bem há requisitos jurídicos a serem observados - a prova de vida.

Art. 538/CC. Considera-se doação o contrato em que uma pessoa, por liberalidade, transfere do seu patrimônio bens ou vantagens para o de outra.

Art. 542/CC. A doação feita ao nascituro valerá, sendo

aceita pelo seu representante legal (BRASIL. Código Civil e normas correlatas, 2020, p. 87).

Essa prova é fundamental para fins da legitimação da personalidade jurídica. Caso em que dependerá de exame médico-legal, uma vez que só o exame da expansão alveolar dos pulmões pela entrada do oxigênio comprovará que o nascituro nasceu com vida. Diagnóstico que é feito utilizando a mais antiga e simples perícia médicolegal denominada de "Docimasia hidrostática pulmonar de Galeno." (FRANÇA, 2011, p. 332).

No caso de natimorto a doação não se concretiza. Ou seja, o bem doado ao nascituro retorna para o doador; porém, se nasceu, respirou e logo depois faleceu o bem se transfere para a mãe da criança.

Prova de que a Medicina Legal é uma disciplina que subsidia o Direito, portanto, exigese dos profissionais do Direito conhecimento dos inúmeros temas abordados por esse ramo da medicina. 


\subsection{ESPÉCIES DE MORTES}

O ordenamento civil especificam diversas espécies de mortes, entre as quais se destacam a morte natural, presumida e por ausência, violenta e suspeita. Referente à morte de causas suspeita e violenta, por ter implicações no âmbito criminal, será apresentada na seção seguinte.

A morte natural - denominada da morte por antecedentes patológicos, ou seja, oriunda de um estado mórbido adquirido ou de uma perturbação congênita (FRANÇA, 2015). Natural ou real é o óbito atestado pelos médicos quando identificam os sinais de cessação da vida.

Morte presumida e por ausência - presume-se morto os ausentes com ou sem decretação. No primeiro caso a lei autoriza a abertura da sucessão definitiva, na forma da segunda parte do artigo 6으 (presume-se morto os ausentes, nos casos em que a lei autoriza a abertura de sucessão definitiva). Neste caso há um processo judicial no qual o juiz, depois de cumpridos os requisitos dos artigos 37 e 38 do CC/02, determina a sucessão definitiva dos bens do ausente.

Já no segundo caso, nos termos do art. $7^{0}$ do $\mathrm{CC}$ refere-se às situações em que 0 corpo não foi encontrado como, por exemplo, nos casos de náufragos, acidentes aéreos catástrofes e prisioneiros desaparecidos. A morte, nessas condições, dispensa a decretação de ausência, pois há evidências de que as pessoas morreram de fato, conforme específica os incisos I, II e parágrafo único desse dispositivo. In verbis:

Art. $7^{\circ}$ Pode ser declarada a morte presumida, sem decretação de ausência:

I - se for extremamente provável a morte de quem estava em perigo de vida;

II - se alguém, desaparecido em campanha ou feito prisioneiro, não for encontrado até dois anos após o término da guerra.

Parágrafo único. A declaração da morte presumida, nesses casos, somente poderá ser requerida depois de esgotadas as buscas e 
averiguações, devendo a sentença fixar a data provável do falecimento. (BRASIL, Código Civil e normas correlatas, 2020, p. 47).

Graças à previsão legal dessa espécie de morte os familiares de vítimas de catástrofe e outros eventos que não deixam vestígios, conseguem garantir os direitos de herança, pensões, seguro de vida, indenizações e outros efeitos jurídicos.

O ordenamento jurídico brasileiro, se vale desse conceito para determinar o fim da personalidade civil do ser humano, ou seja, a morte.

\subsection{MORTE VIOLENTA E DE CAUSAS SUSPEITAS}

Como todos dependem de um documento para comprovar o óbito, entre os grandes desafios da Tanatologia Médico-legal reside em definir o diagnóstico da causa da morte violenta e outros tipos que envolvem matéria do direito penal. Pela abrangência das implicações no âmbito criminal, por demandar longa discussão se faz mister distinguir o que seja apenas violente ou de causas suspeitas.

A morte violenta - tem origem em causas externas. Decorre de condutas praticadas por outrem ou contra a si mesmo, nas quais se incluem os de homicídio, suicídio e acidente e de causas suspeita. Nesses casos pela necessidade da investigação policial e jurídica o cadáver dever ser enviado ao Instituto Médico Legal para atestar a causa da morte, exceto quando não houver infração penal a apurar ou quando pelas lesões externas puder precisar a causa da morte, conforme o parágrafo único do art. 162 do Código Processo Penal:

Parágrafo único. Nos casos de morte violenta, bastará o simples exame externo do cadáver, quando não houver infração penal que apurar, ou quando as lesões externas permitirem precisar a causa da morte e não houver necessidade de exame interno para a verificação de alguma circunstância relevante (NUCCl, 2013, p. 401).

1. No homicídio (art. 121/CP) - É a morte causa por outra pessoa. Pouco importa quem seja a vítima: seja um indivíduo ou aquele que está para nascer e se encontra no ventre materno (aborto criminoso) ou durante o parto (infanticídio) ou até nos casos para abreviar o sofrimento de alguém (homicídio piedoso). 
2. Suicídio - Embora não seja considerado um crime, a morte provocada em si mesmo, não deixa de ser um fato antijurídico, eis que a auto eliminação é uma conduta contrária à ordem jurídica. Tanto o é assim que se pune a tentativa e o induzimento ao suicídio.

3. Instigação ou auxílio ao suicídio (art. 122/CP). A conduta de induzir ou instigar alguém a suicidar-se ou prestar-Ihe auxílio para que o faça é punível com reclusão, sendo ainda a pena agrava pelas qualificadoras quando praticadas por motivo egoístico ou a vitima for menor.

4. A morte de causas suspeita - É aquela que ocorre de forma duvidosa, inclui-se nesse rol a morte súbita, acidental e para a qual não se tem uma evidência de ter sido de causa violenta ou por antecedentes patológicos, portanto, será definida após a perícia tanatológica (FRANÇA, 2015).

Por vezes, pode ser que o exame não se consiga chegar à conclusão quanto se tratar de morte por acidente, suicídio ou crime. Nestes casos, desde que se tenha exaurido todos os meios disponíveis para comprovação da causa mortis recebe a rubrica jurídica de causa indeterminada (FRANÇA, 2015).

Se por um lado a "causa mortis do ponto de vista médico, são todas as doenças, afecções mórbidas ou lesões que ou produziram a morte, ou contribuíram para ela e as circunstâncias do acidente ou violência que produziram quaisquer de tais lesões (CID -10)", por outro, a causa jurídica classificam em natural ou violenta (ALCÂNTARA, 2006, p. 308/9).

\section{CONCLUSÃO}

Vimos que o estudo da Tanatologia não se restringe a um único campo do saber, área acadêmica ou atividade profissional. Tema que vem sendo discutido desde antigas civilizações por filósofos, historiadores, médico, juristas entre outros estudiosos, porém, continua sendo um enigma da existência humana.

A reflexão histórica sob os três pontos de discussão propostos, mostrou em primeiro lugar como a forma de lidar com esse tema vem se transformando ao longo do tempo; 
em segundo, que a morte encontra-se medicalizada, hospitalizada, distante da família e até da sociedade; e, em terceiro, como a Medicina Legal e a Tanatologia estão intrinsicamente associada à Ciência do Direito.

Como pano de fundo da abordagem, por se tratar de livro cujo tema central é tanatologia, procurou-se também chamar atenção para o distanciamento do tema tanto no ensino quanto na prática profissionais. O que faz supor existir uma necessidade de discutir esse tema na formação acadêmica, diante da enorme dificuldade em lidar com as discussões relacionadas à morte e o morrer.

Muito embora os objetivos da disciplina Tanatologia Medicina-legal destinam-se também a capacitar alunos quanto aos aspectos ético-legais do atuar do profissional, o processo da morte vem sendo submetida a um mercantilismo econômico pelas instituições hospitalares.

Com o vertiginoso progresso científico tem-se um crescente predomínio da técnica sobre a doença e a tendência em manter o organismo em funcionamento ao máximo por meio de sofisticados equipamentos, o qual progresso acaba por transformar a doença em objeto de comércio e de lucro.

Nesse contexto, a relação dos profissionais no ambiente hospitalar com a morte tornaram-se impessoal, fria e direta em função até da própria formação tecnicista e fragmentada. Aliado a difícil conciliação do fazer técnico com o cuidado humanizado reflete na dificuldade em falar de morte, conforme mostrou um estudo desenvolvido nos primeiros anos desse século.

Em 2005, Starzewski et. al. (2005) realizou uma pesquisa com os familiares e médicos logo após a morte do paciente. Este estudo demonstrou que as situações mais difíceis que os médicos enfrentam ao conversar com a família são principalmente nos casos de paciente jovens (43,4\%), morte por quadro agudo $(56,6 \%)$ e quando a família não entende o caso (17\%). Quanto à formação acadêmica, apenas 18,9\% dos profissionais consideram a formação adequada sobre o assunto. 
No âmbito do Direito as dificuldades são ainda maiores, eis que em pleno século XXI, causa certa perplexidade se discutir a relevância desse conhecimento para a formação dos profissionais da carreira jurídica. Fato que faz relembrar que desde as mudanças no ensino superior no Império, culminando com expansão das Faculdades de Direito, foi incluída a cadeira de Medicina Legal no ensino jurídico pelo Decreto 9.360, de 17 de janeiro de 1885 como matéria obrigatória, porém, hoje, sequer integra a grade curricular, assim mesmo quando a integra na maioria das faculdades é oferecida como disciplina optativa (BRASIL, Decreto 9.360/1885).

Passada todas essas décadas, a edição da Resolução № 5, de 17 de Dezembro de 2018, a qual reestruturou as Diretrizes Curriculares Nacionais do ensino jurídico no Brasil, não faz menção expressa sobre a exigência da obrigatoriedade do ensino da Medicina Legal nos currículos dos Cursos de Graduação em Direito (BRASIL, Resolução no 5/2018).

Em conclusão, apesar de a morte ser um fato natural e inadiável, falar sobre esse tema sempre foi um assunto cercado de mistérios e angústia. Mesmo aqueles que lidam com a morte no seu dia-a-dia não estão adequadamente preparados para lidar com o fenômeno morte, quiçá para os profissionais do Direito.

\section{REFERÊNCIA}

ABBAGNAMO, Nicola. Dicionário de filosófica. Edição revista e ampliada. São Paulo: Martins Fontes, 2007.

A HISTÓRIA DA FILOSOFIA. Epicuro e a medicina da alma. Nova Cultura, São Paulo, 2004.

ALCÂNTARA, Hermes de. Perícia médica judicial. $2^{2}$ Ed. Rio de Janeiro: Guanabara Koogan, 2006. p. 308/9.

ARAÚJO, Paulo Afonso de. Nada, angústia e morte em ser e tempo, de Martin Heidegger. Revista Ética e Filosofia Política - V. 10, № 2, Dez. 2007. 
ARIÈS, Philippe. História da morte no ocidente. Tradução por Priscila Viana de Siqueira. Rio de Janeiro: Francisco Alves, 1977.

ARIÉS, Philippe. História da morte no Ocidente: da Idade Média aos nossos dias. Rio de Janeiro: Ediouro, 2003.

BRASIL. Código Civil e normas correlatas. 11‥ Ed. Brasília, DF : Senado Federal, Coordenação de Edições Técnicas, 2020.

BRASIL. Resolução ํㅜ 5, de 17 de Dezembro de 2018. Institui as Diretrizes Curriculares Nacionais do Curso de Graduação em Direito e daì outras providências. Disponível em: https://bit.ly/3fAxZtK. Acesso em: 08.08. 2020.

BRASIL. Resolução CFM no 1995, 09 de agosto de 2002. Dispõe sobre as diretivas antecipadas de vontade dos pacientes. Disponível em: https://bit.ly/3gISSUR. Acesso em: 08.08. 2020.

BRASIL. Resolução no 2.173, de 23 de Novembro de 2017. Define os critérios do diagnóstico de morte encefálica. Disponível em: https://bit.ly/33BATVY. Acesso em: 08.08. 2020.

BRASIL. Lei № 9.434, de 4 de Fevereiro de 1997. Dispõe sobre a remoção de órgãos, tecidos e partes do corpo humano para fins de transplante e tratamento e dá outras providências. Disponível em: https://bit.ly/3gHBbVO Acesso em: 08.08.2020.

BRASIL. Decreto 9.360, de 17 de janeiro de 1885. Dá novos Estatutos ás Faculdades de Direito. Disponível em: https://bit.ly/2XECYTR. Acesso em: 08.08. 2020.

BUCHARD, Alan Barbosa. Reflexão tanatológica: dos helenistas a Montaigne. VII Encontro de Pesquisa na Graduação em Filosofia da UNESP. V. 5, 2012, p. 124. Disponível em: https://bit.ly/38BbuD8. Acesso em 08/06/2020. 
EPICURO. A carta sobre a felicidade (A Meneceu). $2^{2}$ reimpressão. Tradução do original Lettera sulla felicità. Tradução e apresentação de Álvaro Lorencini e Enzo Del Carratore. São Paulo: Fundação Editora UNESP. 2002.

EPICURO. Carta sobre a felicidade: a Meneceu. Trad. Álvaro Lorencini, Enzo Del Carratore. São Paulo: UNESP, 1997.

FIGUEIREDO, M.G.M.C.A.; STANO, R.C.M. T. O Estudo da Morte e dos Cuidados Paliativos: uma Experiência Didática no Currículo de Medicina. R. Bras. de Educ. Médica. Vol. 37, № 2, p.298-307, 2013.

FOUCAULT, Michel. 0 nascimento da Clinica. $7^{a}$ Ed. Rio de Janeiro: Forense universitária. 2013.

FRANÇA, Genival Veloso. Medicina Legal. 9ํㅡ. Ed. Rio de Janeiro: Guanabara Koogan, 2011.

FRANÇA, Genival Veloso. Medicina Legal. 10ํㅡ. Edo de Janeiro: Guanabara Koogan, 2015.

FREIRE, José Jozefran Berto, Medicina Legal fundamentos filosóficos. São Paulo; Editora Pillares, 2010.

GOMES, Táuria Oliveira. A ética de Epicuro: um estudo da carta a meneceu. Revista Eletrônica. Mعтavóıa. São João del-Rei, n. 5, p.147-162, jul. 2003.

GOMES, Hélio. Medicina Legal. $31^{a} \stackrel{\text { Ed}}{ }$. Rio de Janeiro: Livraria Freitas Bastos S.A. 1994.

GURGEL, Wildoberto Batista. A morte como questão social. Barbaroi. Santa Cruz do Sul, n. 27, jul./dez. 2007. Disponível em https://online.unisc.br/ seer/index.php/ barbaroi/ article/ view File/138/570 capturado em 10/02/2019.

HEIDEGGER, Martin. Sein und Zeit. Tübingen: Max Niemeyer, 2001. 
HEIDEGGER, M. Ser e Tempo. 14를 Ed. Rio de Janeiro: Vozes, 2005.

HEIDEGGER, Martin. Da essência da verdade. In: Ser e verdade. Trad. Emmanuel Carneiro Leão. Petrópolis: Vozes; Bragança Paulista: Ed. Universitária São Francisco, 2007 a.

HOUAISS, Koogan. Enciclopédia e dicionário ilustrado. Rio de Janeiro: Edições Delta. 2004.

KOVÁCS, Maria Julia. Desenvolvimento da Tanatologia: estudos sobre a morte e o morrer. Paidéia, Ribeirão Preto, vol.18 no.41, 457-468, Sept./Dec. 2008.

MASSON, Cleber. Direito Penal. Vol. 2. Parte especial. Arts. 121 a 212. 11. ed. rev., atual. e ampl. Rio de Janeiro: Forense, São Paulo: MÉTODO, 2018.

MEDEIROS, Luciana Antonieta \& LUSTOSA, Maria Alice. A difícil tarefa de falar sobre morte no hospital. Rev. SBPH, Rio de Janeiro, vol.14 nº.2, dez. 2011.

NUCCl, Guilherme de Souza. Código de Processo penal. 12a Ed. rev. atual. e ampl. São Paulo: Editora Revista dos Tribunais, 2013.

KÜBLER-ROSS, Elisabeth. Sobre morte e morrer: o que os doentes terminais têm para ensinar a médicos, enfermeiros, religiosos e aos seus próprios parentes. Tradução de Paulo Menezes. 8o Ed. São Paulo: Martins Fontes, 1998.

ORIONE, Eduino José. A meditatio mortis montaigniana. Kriterion: Revista de Filosofia, Belo Horizonte, № 126, Dez./2012, p. 463-481.

PEREIRA, Regina Marisol Troca. Diógenes Laércio, livro X: Epicuro -Notas Preliminares e Tradução. Revista Labor Histórico, Rio de Janeiro, no 5, v. 2, p. 443511, jul./dez. 2019. DOI: https//doi.org/10.24206/lh.v5i2.29961.

PLATÃO. Apologia de Sócrates. Tradução: Sueli Maria de Regina. São Paulo: Martin Claret, 2009. 
SÊNECA, Epístolas a Lucíolo, VIII, epístola 70. In: PUENTE, Fernando (Org.). Os filósofos e o suicídio. Belo Horizonte: Ed. UFMG, 2008.

SALVIANO, Jarlee. A metafísica da morte de Schopenhauer. Rev. ethic@Florianópolis, v. 11, n. 2, p. 187-197, julho de 2012.

SILVA, Markus Figueira da. Epicuro e a morte como perda da subjetividade. Revista Princípios, Natal, a. II, n. 3, p. 140-6), Jul./Dez, 1995.

SPLNDOLA, Thelma; Macedo, Maria do Carmo dos Santos. A morte no hospital e seu significado para os profissionais. R. Bras. Enferm. Brasília. v. 47, n.2, p.108-117, abr./jun. 1994.

Starzewski Jr et al. O preparo do médico e a comunicação com familiares sobre a morte. Rev. Assoc. Med. Bras. [online]. 2005, vol.51, n.1, pp.11-16.

SUXO $\mathrm{CH}$, Nestor. Morrir es filosofar. Bolívia. Cochabanba: Editora educación y cultura, 2015.

ZAIDHART, Sérgio. Morte e a formação médica. Rio de Janeiro. Francisco Alves, 1990.

Enviado: Agosto, 2020.

Aprovado: Outubro, 2020. 